\title{
Exploring human security through phenomenological research: A brief review
}

\author{
Otto F. von Feigenblatt*
}

The present paper explores how the concept of Human Security can be approached through phenomenology. First, two phenomenological studies dealing with perceptions of short, mid, and long term threats and structural violence are reviewed and analyzed. A brief literature review dealing with Human Security reveals a dearth of studies from a phenomenological perspective. Finally, a research plan for the study of Human Security is provided to show how an interdisciplinary paradigm usually studied from a critical or constructivist perspective can also be approached from a phenomenological point of view. The paper concludes that phenomenology can fill an important gap between theory and practice in terms of finding links between individual perceptions of Human Security and critical studies of both sociopolitical underdevelopment in emerging nations and structural violence.

Human Security refers to both "freedom from want" and "freedom from fear". It is a concept that has influenced several fields such as international development studies, international relations, and security studies. At the core of Human Security is the concern for the holistic wellbeing of the individual human being. Human Security asserts that in order for an individual to be safe and secure both positive and negative peaces are necessary (Galtung, 1969). Human Security includes the ideal that an individual human being needs both to be physically safe and also to have the opportunity to obtain shelter, employment, education, and other attainments that denote wellbeing. The theory of Human Security was originally developed by the United Nations Development Program in conjunction with the Commission for Human Security (MacFarlane \& Khong, 2006). Human Security combines aspects of human development with aspects of the norm of the responsibility to protect the vulnerable regardless of location or origin by the international community including civil society organizations and foreign governments. This theory was also influenced by the writing on economics of Amartya Sen and the theory of positive peace of Johan Galtung (Galtung, 1969; Sen, 1999). The following section reviews and analyzes two studies dealing with important aspects of $\mathrm{Hu}-$ man Security from a phenomenological perspective.

\section{Two examples of phenomenological research related to human security}

Suffering child: An Embodiment of War and Its Aftermath in Post-Sandinista Nicaragua by James Quesada and Hindu Nationalism, Untouchable Reform, and the Ritual Production of a South Indian Village by Diane P. Mines are two phenomenological studies which deal with two important aspects of human security, namely "freedom from fear"

\footnotetext{
* Otto F. von Feigenblatt is a fellow with the Royal Asiatic Society of Great Britain and Ireland.
} 
and "freedom from want" (Mines, 2002; Quesada, 1998). The two studies were chosen for their holistic approaches to experiences of insecurity and for the vivid descriptions they provide of the phenomenon of human insecurity. The following pages provide a brief summary of each paper as well as an analysis of how the phenomenological approach was applied to the research problems.

Quesada's study of the threats to the human security of a child and his family in post-Sandinista Nicaragua deals with the effects of war from a holistic perspective. The researcher was interested in the entire experience of life under extremely difficult conditions of poverty and structural violence. A phenomenological approach was chosen by Quesada to fill an important gap in the literature. Most studies dealing with post-war societies concentrate on the experiences of adults and those few dealing with children approach the issue from a psychological perspective. According to Quesada, the result of this is that children's experiences are pathologized by mainstream psychological theories and therapy is prescribed as the most important policy solution (Moustakas, 1994; Quesada, 1998, p. 61).

Daniel, a ten year old boy, living in a shantytown on the outskirts of the Nicaraguan city of Matagalpa was interviewed and observed for almost a year in 1991. Quesada interacted with Daniel's family on an almost daily basis during fieldwork. Daniel was chosen as an appropriate co-researcher for the research problem at hand because of his age, family history, and socio-economic condition at the time of the field work. Both of his parents had supported the Sandinista revolution as combatants and Daniel had grown up during the golden years of the revolution. His family experienced a sharp downturn in fortune after the election of the conservative government of Violeta Chamorro and ended up losing their property and jobs, and living a meager existence in a shantytown. The boy suffered from severe malnutrition, did not attend school, and played the role of father and caretaker for his family.

The vivid textural and structural descriptions provided by Quesada based on extended interviews with Daniel and his mother show the chronic nature of the phenomenon of human insecurity from the point of view of the lived experience of Daniel (Moustakas, 1994). Physical violence and chronic hunger are tightly intertwined in Daniel's experience of his life. Quesada also describes the context (the civil war, the embargo, neo-liberal reform, etc.) in which the human insecurity came to be. In summary Quesada's study shows that Daniel's life experiences after the war as defined by chronic "fear" and "want", the two opposites of human security. Finally, Daniel reaches the following conclusion about what to do with his life since he lacks human security:

Look at me, I'm all bones anyway, I'm already dying. I'm too small and I've stopped growing and I am another mouth to feed. My mother can't keep taking care of my brother and me, and I can't keep taking care of her. I can't do anything. So it would be better if I just died since that would help everyone (Quesada, 1998, p. 60).

A second example of a phenomenological study dealing with Human Security is Hindu Nationalism, Untouchable Reform, and the Ritual Production of a South Indian Village by Diane P. Mines (Mines, 2002). The study took place from 1989 to 1990 in the village of Yanaimangalam in the province of Tamilnandu, India (Mines, 2002, p. 58). Ritual production was the process that was studied, but the specific phenomenon that was experienced was that of "empowerment". More specifically Diane P. Mines interviewed and observed how untouchables in Yanaimangalam organized a religious festival with the goal of achieving empowerment for their caste. Mines was interested in how villag- 
ers from the untouchable caste experienced the festival and therefore chose to conduct a phenomenological study of the event. Her goal was to elicit rich textural descriptions of the experience of empowerment and thus to better understand how the ritual elicited that feeling/experience. The study includes a thorough literature review dealing with ethnographic studies of the region. Historical background of the marginalization of untouchables in the village as well as the entire country is also provided.

The study concludes that the untouchables in the village experienced organizing their own religious festival as an empowering experience in which they achieved momentary equality vis-à-vis the other villagers. Moreover, by appropriating national symbols such as the untouchable hero, Ambedkar, they regained a sense of agency in their lives. By horizonalizing the descriptions provided by the co-researchers, Diane P. Mines was able to construct a proper textural and structural description of the experience of empowerment (Creswell, 2007, p. 60; Mines, 2002, p. 75; Moustakas, 1994).

The two studies reviewed deal with important aspects of human security from a phenomenological perspective. The experience of a lack of "freedom from want" and "freedom from fear" are both addressed in the studies and thus complement the literature on the subject. The phenomenological approach provided rich descriptions of the experiences of "empowerment" and human insecurity form the point of view of those actually experiencing them. It should be noted that their approaches to phenomenological research greatly differ from that espoused by Moustakas. Mines combines some aspects of ethnographical research to phenomenology such as participant observation and some documentary research (Mines, 2002). This means that her findings are not only based on the perceptions and experiences of the people she interviewed but are also affected by her own observations as a participant observer and by the literature on the subject (Mines, 2002, p. 83). In Moustaka's terms, Mines did not bracket her own experiences appropriately (Moustakas, 1994). Quesada's approach also combines some aspects of case study research to phenomenology. His report includes documentary research and he combined findings derived from formal interviews with casual observations and interactions that he had with Daniel and his family (Quesada, 1998). Also, he clearly states that he is biased in favor of empowerment and thus he too did not bracket his own experiences appropriately (Quesada, 1998, p. 69). Both Mines and Quesada used a looser approach to interpretation of the interviews, and they did not engage in the careful coding and division of textural and structural divisions that Moustakas advocates (Mines, 2002; Moustakas, 1994; Quesada, 1998).

\section{Exploring the phenomenon of human insecurity in the Thai South}

Following the examples provided in the previous section, a study of the phenomenon of Human Insecurity in the Thai South could be designed by following a phenomenological approach. Most research on the topic of intrastate security and counterinsurgency concentrates on the militants and security forces rather than on the experiences of the children and adolescents living in areas affected by the insurgency (Glassman, 2005; Liow, 2006; "Thailand: Political Turmoil and the Southern Insurgency ", 2008; Yegar, 2002). The few studies dealing with the lived experiences of non-combatants follow an ethnographic approach (Coalition-to-Stop-the-Use-of-Child-Soldiers, 2008; McCargo, 2008; Roux, 1998). Another group of studies written from a critical perspective follow a constructivist approach and concentrate on the normative contestation involved in the struggle (Feigenblatt, 2009, 2010 (in press); Perkasa, 2008; Syukri, 1985). There is a clear gap in the literature in terms of a lack of studies dealing with how children and 
teenagers experience the turmoil. It would be fruitful to apply the human security theoretical framework to a phenomenological study of the previously mentioned phenomenon. The theory of Human Security was originally developed by the United Nations Development Program in conjunction with the Commission for Human Security (MacFarlane \& Khong, 2006). Human Security combines aspects of human development with aspects of the norm of the responsibility to protect. This theory was also influenced by the writing on economics of Amartya Sen and the theory of positive peace of Johan Galtung (Galtung, 1969; Sen, 1999).

\section{A proposed phenomenological study of the experience of human insecurity from the point of view of children and teenagers in the Thai South}

How do children and teenagers experience human insecurity in the Thai South? The question can be subdivided into two more specific questions dealing with the two main components of human security: How have you experienced the lack of physical safety? How have you experienced lack of food and other basic goods? How has that insecurity made you feel? Based on the main research problem and two main questions, several phenomenological interview questions can be administered to participants in order to elicit rich descriptions of different aspects of the phenomenon labeled "human insecurity" (see appendix for sample interview questions). This proposed study would take place in the Deep South of Thailand (Greater Patani and Narathiwat) over a period of one and a half years and would involve at least ten co-researchers from the main provinces. Children and teenagers would be selected to participate in the study according to their life experiences so as to identify those who have experienced both a lack of "freedom from fear" and "freedom from want" due to the unrest in the region.

\section{Conclusion}

The present paper shows how the phenomenological approach can be applied to the study of the broad concept of human security. Two examples of phenomenological studies dealing with aspects of human security were provided and analyzed. A proposed plan for a research study dealing with the phenomenon of human insecurity from the point of view of children and teenagers in the Thai South was also included. From a methodological perspective, the research problem derives from both the literature review and the author's experiences in the region. Finally, the horizonalization involved in the phenomenological study of lived experience equalizes the discursive importance of the experiences of the co-researchers and is thus an excellent approach for studying the "subaltern", the marginalized, and the dependent (Moustakas, 1994).

\section{References}

Coalition-to-Stop-the-Use-of-Child-Soldiers. (2008). Child Recruitment and Use in Southern Thailand [Electronic Version]. Report. Retrieved February 7, 2009, from http://www.humansecuritygateway.info/documents/CSUCS_ChildRecruitment_Th ailand.pdf

Creswell, J. W. (2007). Qualitative Inquiry \& Research Design: Choosing Among Five Approaches (Second ed.). London: SAGE Publications. 
Feigenblatt, O. F. v. (2009). The Thai Ethnocracy Unravels: A Critical Cultural Analysis of Thailand's Socio-Political Unrest. Journal of Alternative Perspectives in the Social Sciences, 1(3), 583-611.

Feigenblatt, O. F. v. (2010 (in press)). The Malay Minority in Southern Thailand: A "Small People" Facing Existential Uncertainty. Ritsumeikan Journal of Asia Pacific Studies, 26.

Galtung, J. (1969). Violence and Peace. Journal of Peace Research, 167-191.

Glassman, J. (2005). The "War On Terrorism" Comes To Southeast Asia. Journal of Contemporary Asia, 35(1), 3-28.

Liow, J. C. (2006). Muslim Resistance in Southern Thailand and the Southern Philippines: Religion, Ideology, and Politics. Washington, D.C.: East-West Center.

MacFarlane, S. N., \& Khong, Y. F. (2006). Human Security and the UN: A Critical History (1st Edition ed.). Indianapolis: Indiana University Press.

McCargo, D. (2008). Tearing Apart the Land: Islam and Legitimacy in Southern Thailand (First ed.). Ithaca: Cornell University Press.

Mines, D. P. (2002). Hindu Nationalism, Untouchable Reform, and the Ritual Production of a South Indian Village. American Ethnologist, 29(1), 58-85.

Moustakas, C. (1994). Phenomenological Research Methods. Thousand Oaks: SAGE Publications.

Perkasa, K. (2008). Patani: Behind the Accidental Border. Los Angeles: KijangMas Perkasa.

Quesada, J. (1998). Suffering Child: An Embodiment of War and Its Aftermath in PostSandinista Nicaragua. Medical Anthropology Quarterly, 12(1), 51-73.

Roux, P. L. (1998). To be or not to be: The Cultural Identity of the Jawi (Thailand). Asian Folklore Studies, 57(2), 223-255.

Sen, A. (1999). Development as Freedom. New York: Anchor Books.

Syukri, I. (1985). History of the Malay Kingdom of Patani (C. Bailey \& J. N. Miksic, Trans.). Athens: Ohio University.

Thailand: Political Turmoil and the Southern Insurgency [Electronic. (2008). Version]. Retrieved February 7, 2009, from http://www.humansecuritygateway.info/ documents/ICG_Thailand_PolTurmoil_Insurgency.pdf

Yegar, M. (2002). Between Integration and Secession: The Muslim Communities of the Southern Philippines, Southern Thailand, and Western Burma/Myanmar. New York: Lexington Books.

\section{Appendix}

\section{Research problem}

How do children and teenagers experience human insecurity in the Thai South?

\section{Subtopics}

How do children and teenagers experience the lack of "freedom from fear"? How do children and teenagers experience the lack of "freedom from want"? 
1. How did the experience of physical insecurity or possibility of bodily harm affect you?

2. How did your physical insecurity make you feel?

3. How did the experience of physical insecurity or possibility of bodily harm affect your family and relatives?

4. Please describe the experience of physical insecurity in the Thai South.

5. Please tell me about how you experienced the lack of basic goods?

6. Please tell me about how the combined experience of both physical insecurity (possibility of bodily harm) and the lack of basic goods affect you and your family?

7. Is there anything else you would like to tell me about the overall experience and how it made you feel? 